\title{
Coparental Conflict and Triangulation, Emotion Regulation, and Externalizing Problems in Adolescents: Direct and Indirect Relationships
}

\author{
Mariana Rodrigues Machado ${ }^{1}$ (D) https://orcid.org/0000-0002-7111-3710 \\ Clarisse Pereira Mosmann² (D) https://orcid.org/0000-0002-9275-1105
}

\begin{abstract}
Difficulties in coparenting performance reverberate in externalizing problems in adolescents. However, understanding on the mechanisms mediating this relationship is scarce. Emotion regulation is a possible link between these constructs. This study aims to test a structural model in which emotional dysregulation mediates coparenting and externalizing problems in adolescents. This is a quantitative, cross-sectional, and explanatory study. The sample consisted of 229 adolescents aged between 11 and 18 , living in inland cities of Rio Grande do Sul. Structural equation modeling was used to test the empirical validity of the proposed theoretical model. Results provided evidence for the advance of the study on family relationships and explanatory mechanisms in the development of externalizing problems. Some domains of emotion deregulation mediate the association between coparenting negative dimensions and externalizing problems. Direct and indirect relationships between the model variables are analyzed and discussed.
\end{abstract}

Keywords: behavior disorders, emotional regulation, family relations

\section{Conflito e Triangulação Coparental, Regulação Emocional e Problemas Externalizantes em Adolescentes: Relações diretas e indiretas}

\begin{abstract}
Resumo: Dificuldades no exercício da coparentalidade reverberam em problemas externalizantes em adolescentes. Entretanto, há escassez no entendimento sobre mecanismos que medeiam essa relação. A regulação emocional apresenta-se como possível ligação entre esses construtos. O objetivo deste estudo foi testar um modelo estrutural no qual a desregulação emocional é mediadora entre coparentalidade e problemas externalizantes em adolescentes. Trata-se de estudo com delineamento quantitativo, transversal, explicativo. Contou com uma amostra de 229 adolescentes entre 11 a 18 anos, residentes no interior do Rio Grande do Sul. Foi utilizada modelagem de equações estruturais para testar a validade empírica do modelo teórico proposto. Os resultados forneceram evidências para o avanço do estudo das relações familiares e mecanismos explicativos no desenvolvimento de problemas externalizantes. Alguns domínios de desregulação emocional são mediadores da associação entre dimensões negativas de coparentalidade e problemas externalizantes. As relações diretas e indiretas entre as variáveis do modelo são analisadas e discutidas.
\end{abstract}

Palavras-chave: distúrbios do comportamento, regulação emocional, relações familiares

\section{Conflicto y Triangulación Coparental, Regulación Emocional y Problemas de Externalización en Adolescentes: Relaciones Directas e Indirectas}

\begin{abstract}
Resumen: Las dificultades en la coparentalidad reverberan en problemas de externalización en adolescentes. Sin embargo, existe una falta de comprensión sobre los mecanismos que median esta relación. La regulación emocional es un posible vínculo entre estos constructos. El objetivo de este estudio fue probar un modelo estructural en el que la desregulación emocional es mediadora entre la coparentalidad y los problemas de externalización en adolescentes. Este es un estudio cuantitativo, transversal y explicativo. Cuenta con una muestra de 229 adolescentes entre 11 y 18 años que viven en el interior de Rio Grande do Sul. Se utilizó el modelo de ecuaciones estructurales para probar la validez empírica del modelo teórico propuesto. Los resultados proporcionaron evidencia para el avance del estudio de las relaciones familiares y los mecanismos explicativos en el desarrollo de problemas de externalización. Algunos dominios de desregulación emocional median la asociación entre las dimensiones negativas de los problemas de coparentalidad y problemas de externalización. Se analizan y discuten las relaciones directas e indirectas entre las variables del modelo.
\end{abstract}

Palabras clave: trastornos de la conducta, regulación emocional, relaciones familiares

${ }^{1}$ Faculdade Especializada na Área de Saúde do Rio Grande do SulFASURGS, Passo Fundo-RS, Brazil

${ }^{2}$ Universidade do Vale do Rio dos Sinos, São Leopoldo-RS, Brazil

Article derived from the first author's master's thesis under the supervision of the second, defended in 2016, in the Programa de Pós-Graduação em Psicologia, Universidade do Vale do Rio dos Sinos. This study was held with the support of the Coordination for the Improvement of Higher Education Personnel - Brazil (CAPES) - Financing Code 001.

Correspondence address: Mariana Rodrigues Machado. Faculdade Especializada na Área de Saúde do Rio Grande do Sul. Rua Angélica Otto, 160, Boqueirão. Passo Fundo-RS, Brazil. CEP 99.025-270. E-mail: mariana.rmachado@yahoo.com.br
After nearly three decades of studies on emotion regulation and child development, several studies show deficits in emotion regulation are associated with externalizing problems in children and adolescents (Aldao, Gee, De Los Reyes, \& Seager, 2016; Gross, 2014; Halligan et al., 2013). These researches show that difficulties emotion regulation resulting from impulse control problems reverberate into risky and impulsive behaviors. They are also a key mechanism in the emergence of specific forms of antisocial behavior. For example, systematic review by Aldao et al. (2016) 
found 59 studies investigating the positive association between difficulties in emotion regulation and externalizing and internalizing problems in children and adolescents. Specifically, difficulties in understanding emotions, in expressing appropriate emotions and ruminative thoughts associated with increased aggressive behavior, inappropriate eating behavior, and increased anxiety.

The externalizing disorders label is applied to various problematic behaviors; it identifies conflicts with others and the child or adolescent's non-compliance with expected behavioral patterns. They relate to aggression, hyperactivity/ impulsivity, social problems and antisocial behavior (Achenbach \& Rescorla, 2001; Achenbach, Ivanova, Rescorla, Turner, \& Althoff, 2016; Mullin \& Hinshaw, 2007). Patterns of inattention, impulsivity, and hyperactivity are statistically associated with aggressiveness and antisocial behavior in most samples, but important distinctions are visible. Aggressive acts that occur when the child is emotionally aroused and defensive reactions to a threat perceived in the environment are called reactive aggression. In turn, those that constitute premeditated behaviors, nonprovoked by the environment, usually designed to achieve personal gain, are called proactive aggression. High negative reactivity and difficulties in emotion regulation are associated with reactive but not proactive aggression (Mullin \& Hinshaw, 2007).

Although externalizing problems have traditionally been conceptualized as difficulties in behavior and cognition, these conditions are closely linked with emotional processes. Research has shown that children who constantly exhibit aggressive and environment reactive behaviors tend to be less able to understand social signals, which results in misinterpretation and incorrect processing of social information (Barros \& Silva, 2006; Mullin \& Hinshaw, 2007). However, they are also more likely to feel angry, act impulsively and have a low level of emotion regulation (Aldao et al., 2016; Eisenberg et al., 2001). Some children tend to have forms of reactive aggression to regulate their experience of certain emotions, such as anger (Mullin \& Hinshaw, 2007).

This propensity can occur in children and adolescents exposed to hostile family models (Barros \& Silva, 2006). Currently, literature provides consistent results indicating that conflicting family environments and exposure to interparental hostility generate emotional dysregulation and, consequently, aggressive and hostile behaviors in the offspring (Davies \& Martin, 2013; Davies, Hentges, et al., 2016; Goulart, Wagner, Barbosa, \& Mosmann, 2015). Parental conflict can be considered a stressor that increases negative emotions and makes children employ strategies to regulate their emotions (Davies \& Martin, 2013; Davies, Hentges, et al., 2016; Davies, Martin, Sturge- Apple, Ripple, \& Cicchetti, 2016). One of the possible strategies is to develop aggressive responses attempting to restore their emotional security regarding parental conflict (Davies \& Martin, 2013; Davies, Hentges, et al., 2016; Davies, Martin, Coe, \& Cummings, 2016).

Emotional security theory has more than two decades of empirical research and investigates the implications that parental conflict has for the offspring's mental health. This theory basic premise is that in an environment of parental conflict children try to maintain their emotional security. Attachment theory has a strong influence on this theory; however, the authors propose that the experience with parental conflict is different from the parent - child relationship. Thus, one can understand emotional security as a product of the child's past experiences with parental conflict and as a primary way to guide future responses when faced with conflict. The effects of emotional insecurity affect how children regulate their emotions (Davies \& Martin, 2013).

In this evaluation context, studies focusing on the family influence on emotion regulation during adolescence are rare (Riediger \& Klipker, 2014). Although research advances with initiatives to understand the complex link between family and emotion regulation, some authors still point to the need for progress in this area, given that the family context involves several interconnected and interdependent subsystems (Teubert \& Pinquart, 2010; Thompson, 2014). Recent studies on the Brazilian population show that, among the family subsystems, difficulties in coparenting influence more the development of psychopathologies in the offspring than marital and parenting difficulties (Mosmann, Costa, Silva, \& Luz, 2018; Mosmann, Costa, Einsfeld, Silva, \& Koch, 2017).

Coparenting is a collaborative involvement of parents or caregivers aiming at education, training, and decision making on their children's lives (Lamela, Nunes, \& Figueiredo, 2010Marsanić \& Kusmić, 2013). Margolin, Gordis and John (2001) defined dimensions such as conflict, cooperation and triangulation. Conflict is expressed when parents disagree on their children's education, presenting criticism, sabotage and disunity. Cooperation is the positive dimension of coparenting and refers to supportive behavior on the children's education and respect between parents. Finally, triangulation concerns one or both parents involving the child in their conflicts.

The implications of coparenting to adolescence suggest that difficulties in coparenting involving conflict and triangulation may lead to internalizing and externalizing problems in the children (Riina \& McHale, 2014). Some international studies have sought to investigate this relationship. Buehler and Welsh (2009) investigated how coparental triangulation may generate internalizing and externalizing problems in adolescents. The longitudinal study evaluated 320 U.S. families. Participants were evaluated annually for four years. The results showed that triangulation was associated with increased internalization and externalization problems and difficulty to control hostility between the couple. They also suggested the social and relational functioning of adolescents may be negatively affected by coparental triangulation.

Although several studies identify associations between externalizing problems and emotion regulation (Aldao et al., 2016; Coutinho, Ribeiro, Ferreirinha, \& Dias, 2010; Eisenberg et al., 2001; Halligan et al., 2013; 
Mullin\&Hinshaw, 2007), theareahas somegaps. Investigation on the relationship between coparenting and the development of emotion regulation in childhood and adolescence is still deficient. Notably, adolescence is a crucial stage in the process of emotion regulation, since it is the moment when temperament, neurobiological, cognitive, psychological and social aspects begin to work together and more independently when compared to childhood (Gross, 2014). Relevant, but showing incipient results, some studies discuss possible differences between father and mother exercising coparenting in this context (Marsanić \& Kusmić, 2013). Still, some studies investigate the effect of age on understanding family core difficulties, suggesting adolescents might identify interparental disagreements and resulting emotions more easily (Davies, Martin, Coe, et al., 2016), highlighting the need for national studies from this population's perspective.

Clearly, understanding the processes that link coparental triangulation and conflict with the development of emotional and behavioral problems is important for future research (Schoppe-Sullivan, Weldon, Cook, Davis, $\&$ Buckley, 2009). How this influence occurs still needs to be clarified. In this sense, difficulties in emotion regulation are consequences of difficulties in family relationships and reverberate in emotional and behavioral problems (Davies \& Martin, 2013). Investigations developed so far did not identify the characteristics of associations, whether direct or indirect, between the variables. Understanding this data may show how externalizing problems are developed, considering that indirect relationships indicate mediating variables between two constructs (Hair, Black, Babin, Anderson, \& Tatham, 2009).

Focusing on clarifying these associations, this study aims to test a structural model in which emotion dysregulation mediates coparenting and externalizing problems in adolescents. With a quantitative, cross-sectional and explanatory design, we aimed to test two hypotheses: (1) difficulties in emotion regulation partially mediate the relationships between coparenting and externalizing problems in adolescents; (2) coparenting has a direct impact on externalizing problems.

\section{Method}

\section{Participants}

Total sample consisted of 229 adolescents, living in Rio Grande do Sul, selected by convenience criterion. As an inclusion criterion, adolescents should live with one of their biological parents and have caregivers carrying out the function of father and mother. Adolescents with a single parent were excluded. The participants' mean age was 14.56 $(S D=1.97)$, with a minimum age of 11 and maximum of 18. The number of participants was determined based on the sample calculation proposed by Hair et al. (2009), considering the minimum number of 200 samples to calculate structural equation modeling.

\section{Instruments}

Sociodemographic Questionnaire. Consisting of 24 questions on sociodemographic data such as sex, age, education, city, number of siblings, etc.

The Coparenting Inventory for Parents and Adolescents (CI-PA, Teubert \& Pinquart, 2011). The scale evaluates both parents and adolescents' perspective on the phenomenon. It is composed of three parts: the coparenting dyad, mother's contributions, and father's contributions; each with three subscales (cooperation, conflict, and triangulation) with four items each. It has questions such as "My mother is stricter than my father." In this study, we only used the part that evaluates the adolescents' perspective in relation to coparenting. Items are scored on a Likert scale from 0 to 4 , in which $0=$ definitely not and $4=$ definitely. CI-PA, in English, was not translated into Portuguese. We translated and Back Translated it for this study. Three bilingual translators compared their versions of the scale to identify discrepancies in translations, then translated into the source language and compared it with the original document to verify accuracy. Cronbach's alpha were 0.75 for mother coparental conflict, 0.83 for mother coparental triangulation, 0.77 for father coparental conflict, 0.89 for father coparental triangulation, 0.71 for family coparental conflict, and finally 0.81 for family coparental triangulation. Evidence of validity for the Brazilian population is described in an article submitted for publication.

Difficulties in Emotion Regulation Scale DERS (Gratz \& Roemer, 2004, translated by Coutinho et al., 2010). The scale assesses typical levels of difficulties in emotion regulation. It was elaborated by (Gratz \& Roemer, 2004) and has six domains: (1) nonacceptance of emotional responses; (2) difficulty engaging in goal - directed behavior; (3) impulse control difficulties; (4) limited access to emotion regulation strategies; (5) lack of emotional awareness; (6) lack of emotional clarity. Coutinho et al. (2010) translated it and Veloso, Gouveia and Dinis (2011) validated it for Portugal. The scale was adapted to Brazilian Portuguese and to the adolescent public. It contains 36 items on a 5 - point Likert scale $(1=$ "it almost never applies to me" to $5=$ "it almost always applies to me"), with items such as: "I am aware of my feelings." In the original study, the scale revealed high internal consistency values $(\alpha=0.93)$, good test-retest fidelity (rs $=0.88)$ and adequate construct and predictive validity. Cronbach's alpha value of the dimensions found for this study was 0.82 for nonacceptance of emotional responses, 0.83 for limited access to emotion regulation strategies, 0.85 for impulse control difficulties, 0.73 for difficulty engaging in goal - directed behavior, 0.78 for lack of emotional awareness, and 0.63 for lack of emotional clarity.

Youth Self-Report Inventory for youth aged from 11 to 18 (YSR, Achenbach \& Rescorla, 2001). Achenbach developed it and Bordin et al. (2013) validated it to use in Brazil. YSR consists of eight scales of behavioral problems. In this study, we used the classification in levels, specifically using the classification in externalizing problems, 
which covers the Rule Breaking and Aggressive Behavior scales, with items such as: "I do not respect the rules of my house, school or other places." The answers are organized on a 3 - point Likert scale in which $0=$ not true and $2=$ always true. This study obtained Cronbach's alpha of 0.75 for Rule Breaking and 0.84 for Aggressive Behavior.

Antisocial Behavior Scale- ABS (Grangeiro, 2014). The scale was developed in Brazil to evaluate antisocial behaviors. It is composed of 36 assertions that verify the frequency of participation in situations such as: "Participate in gang fights," based on five - point Likert - type answers: $0=$ never done and $4=$ already done six or more times. The scale is divided into two dimensions: Mild Antisocial and Severe Antisocial, obtaining in the original study Cronbach's alpha of 0.87 and 0.88 respectively. In this study, Cronbach's alpha values for the scale were 0.88 for Mild Antisocial and 0.66 for Severe Antisocial.

\section{Procedure}

Data collection. Data was collected individually and collectively in public and private schools in Rio Grande do Sul. A total of 306 adolescents were invited by referrals from the research team and four schools from inland cities of Rio Grande do Sul state were selected by convenience. In the collection in schools, the coordination team of each school was contacted to present the objectives of the study. We invited students to participate in the study and informed that their participation was voluntary. Students received an informed consent form (ICF) that should be signed by their parents or guardians, and adolescents signed an informed consent form for minors. Afterwards, the instruments were administered collectively in the groups with two researchers in each classroom. The individual collection took place at the participating adolescents' residence with a researcher. Only the adolescents whose parents signed the informed consent form participated in the study. The instruments administration lasted around 90 minutes.

Data analysis. Data analysis consisted in descriptive calculations and bivariate correlations. To evaluate the hypothesis that difficulties in emotion regulation is a mediating variable between coparenting and externalizing problems in adolescents, we used structural equation modeling (SEM). The estimation method used was Maximum Likelihood of probability with AMOS software. Also, we tested whether coparenting has a direct impact on externalizing problems.

Three latent variables composed the model: Coparenting (exogenous), Difficulty in Emotion Regulation (endogenous), and Externalizing Problems (endogenous). The model variables were composed according to Byrne (2010). To measure coparenting, the following measures were analyzed: mother triangulation; father triangulation; family triangulation; father coparental conflict, mother coparental conflict; family coparental conflict; father coparental cooperation; family coparental cooperation, and mother coparental cooperation. Similarly, for the latent variable Difficulty in Emotion Regulation, the following measures were analyzed: difficulty in accepting emotions, difficulty in employing emotional management strategies, difficulty in emotional clarity, difficulty in emotional awareness, difficulty in reaching goals, and difficulty in controlling impulses for emotion regulation. To analyze the externalizing problems, they were added to the dimensions of Rule Breaking and Aggressive Behavior of the Youth Self-Report Inventory (YSR) and to the dimensions of Mild Antisocial Behavior and Severe Antisocial Behavior of the Antisocial Behavior Scale.

The adequacy analysis of the structural equation model was performed using the main adjustment measures: chi-square $\left(\mathrm{X}^{2}\right)$; root mean square error of approximation (RMSEA); normed fit index (NFI); comparative fit index (CFI), Tucker Lewis index (TLI). To adjust the model, the RMSEA value was less than 0.08. For NFI, CFI, and TLI, values higher than 0.9 were considered satisfactory (Hair et al., 2009).

\section{Ethical Considerations}

This project is approved under number 14/152 of the Research Ethics Committee of the Universidade do Vale do Rio dos Sinos, according to Resolution 466/12 of the Brazilian National Health Council, which regulates research with human beings in Brazil. We assured for the adolescents the confidentiality of all information, that participation was voluntary and that they could abandon the research at any time.

\section{Results}

Initially, data on descriptive statistics were analyzed. The sample consisted of 115 boys (50.4\%) and 113 girls (49.6\%). Most adolescents were in nuclear families $(73.8 \%$, $n=169)$, and the $26.2 \%$ left correspond to separated and remarried families. Of these, $7.4 \%(n=17)$ of fathers and $9.6 \%(n=22)$ of mothers are currently in new unions.

Regarding the adolescents' education, $45 \%(n=103)$ were attending elementary school, $54.6 \%(n=125)$, high school and only $0.4 \%(n=1)$, higher education. Also, $90.4 \%$ of the adolescents were enrolled in public schools, $3 \%$ in private schools, and $6.6 \%$ did not give this information.

Regarding psychological treatment, 85.6\% never performed any kind of follow-up or psychological treatment. However, among the $14 \%$ who said they had psychological follow-up, the mean treatment time was five months. Currently, only one adolescent is reportedly undergoing treatment.

Table 1 shows correlations between the model variables.

The proposed structural model was based on the hypothesis that difficulties in emotion regulation partially mediate the relationships between coparenting and externalizing problems in adolescents. Also, we tested the hypothesis that coparenting directly impacts externalizing problems. 


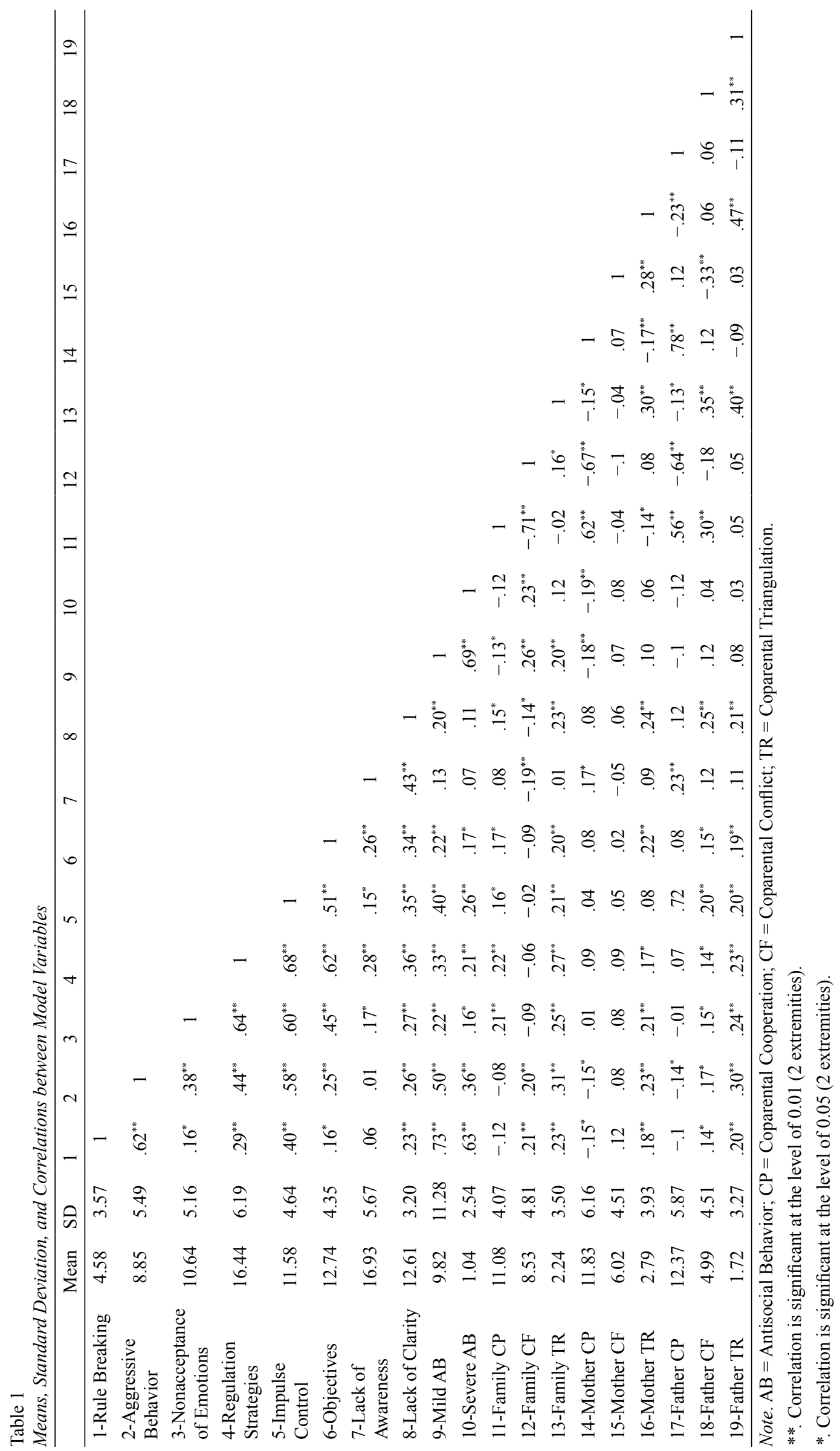


A structural model encompasses the specification of the structural relations between the constructs, i.e., whether they are related or not. Following the steps proposed by Hair et al. (2009) to construct a structural model, we first tested a measurement model with all variables that presented inadequate adjustment with insufficient indices: $\chi^{2}=629, p=0.000, \chi^{2} / \mathrm{df}=$ $3.38, \mathrm{RMSEA}=0.11, \mathrm{CFI}=0.750, \mathrm{TLI}=0.713, \mathrm{NFI}=0.700$. The following variables did not present significant associations, therefore were excluded from the model: Family Coparental Cooperation $(\beta=0.806, p>0.22)$, Mother Coparental Conflict $(\beta=-0.093, p>0.29)$, Father Coparental Cooperation $(\beta=-0.860, p>0.08)$, Mother Coparental Cooperation $(\beta=-0.195, p>0.14)$, Family Coparental Conflict $(\beta=0.890$, $p>0.25)$, and Emotional Awareness $(\beta=0.310, p>0.29)$. We adjusted the covariance between Mild Antisocial Behavior and Severe Antisocial Behavior, between father coparental conflict and mother coparental triangulation, between Rule Breaking and Severe Antisocial Behavior, between Aggressive Behavior and Mild Antisocial Behavior, and between father coparental conflict and family coparental triangulation. The final measurement model obtained the following indices: $\chi^{2}=122.97, p=0.000$, $\chi^{2} / \mathrm{df}=2.15, \mathrm{RMSEA}=0.80, \mathrm{CFI}=0.943, \mathrm{TLI}=0.922$, $\mathrm{NFI}=0.901$.

Figure 1 presents the path diagram results of the structural model. The model standardized regression coefficients show that the magnitude of prediction of difficulties in coparenting exercise to difficulties in emotion regulation is moderate $(\beta=0.41 ; p<0.001)$, which also moderately impacts in externalizing problems in adolescents $(\beta=0.44 ; p<0.001)$. The direct path between coparental conflict and triangulation and externalizing problems remained, but with weak impact $(\beta=0.14 ; p<0.001)$.

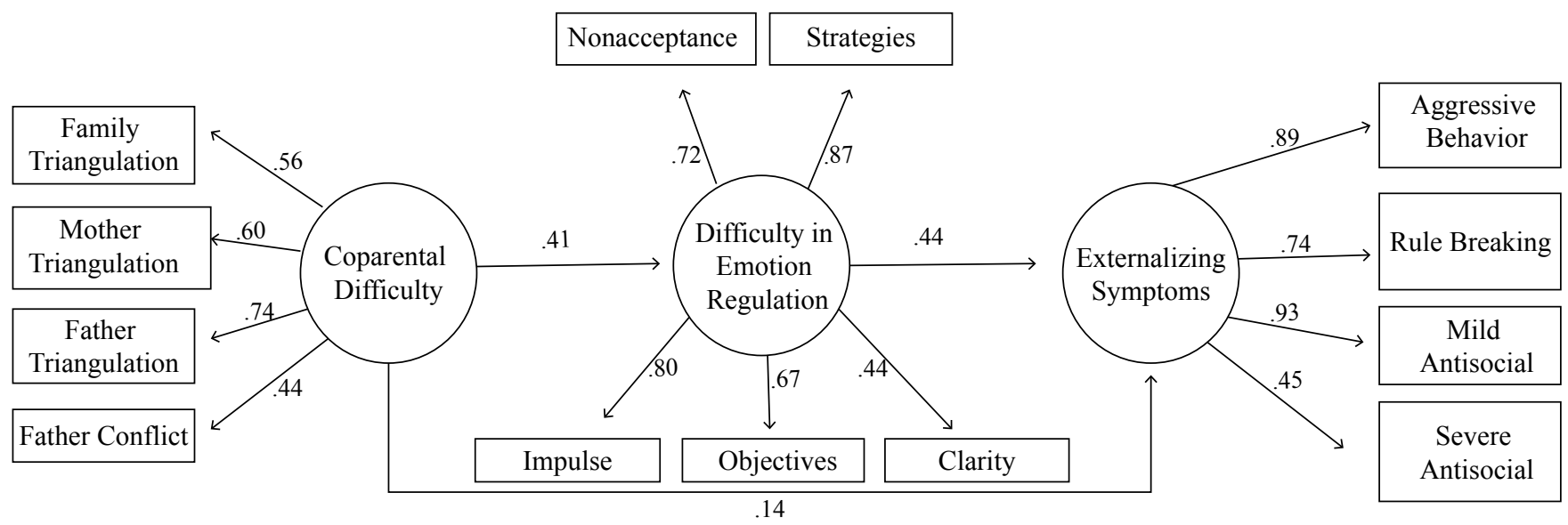

Figure 1. Final structural model.

Mediation eases the relationship between two constructs and requires significant correlation between the three constructs individually. According to (Hair et al., 2009), we should perform some analyses to verify the extent of the model mediating effect. The first step is to verify individually whether the direct effect between the latent constructs was significant. Thus, impact occurred between: Coparenting negative dimensions for Externalizing Problems $(\beta=0.31$; $p<0.001)$; Coparenting negative dimensions for Difficulties in Emotion Regulation ( $\beta=0.42 ; p<0.001)$; and Difficulties in Emotion Regulation and Externalizing Problems $(\beta=0.46$; $p<0.001)$. Subsequently, the relationship between the variables was analyzed. The relationship between Coparenting negative dimensions and Externalizing Problems reduced the effect when the latent variable Difficulties in Emotion Regulation was included in the model. This indicates partial mediation of Emotion Regulation, since the direct relationship remained significant, although it was reduced from $(\beta=0.31$; $p<0.001)$ to $(\beta=0.14 ; p<0.001)$ (Hair et al., 2009).

The original theoretical model assumed two hypotheses: (1) that Difficulties in Emotion Regulation partially mediated the relationships between Coparenting and Externalizing Problems. Additionally, it also assumed the hypothesis (2) in which a path directly connected Coparenting and Externalizing Problems, thus characterizing a partial mediation. The hypotheses were confirmed, indicating the existence of direct and indirect paths between the constructs. The existence of indirect path is consistent with mediation. Thus, a partial mediation of Difficulties in Emotion Regulation confirmingly exists between Coparenting and Externalizing Problems in this study. Finally, it is emphasized that only the negative dimensions of Coparenting-Coparental Triangulation and Conflict - remained significant in the empirical model.

\section{Discussion}

Overall, the final results highlight the importance of examining the processes of coparental triangulation and conflict and the impact they have on the development of externalizing problems in adolescents. This association is consistently supported by previous studies (Davies \& Martin, 
2013; Riina \& McHale, 2014; Schoppe-Sullivan et al., 2009). Also, the model results indicate that emotion regulation is a mediating variable between coparental triangulation and conflict and externalizing problems.

In this sense, the model proves the character of partial mediation, confirming hypothesis 1 . To understand this finding is possible by considering the emotional security theory, which postulates that when children notice a threat in the environment, they have difficulties managing their emotions, which is perceived in the moderate to high results of difficulties in emotion regulation (Davies \& Martin, 2013). As a result, they tend to respond reactively, which is proven when considering the impact of the problem dimensions of controlling impulsive behavior $(\beta=0.80 ; p<0.001)$ and limited access to emotion regulation strategies $(\beta=0.87 ; p<0.001)$, resulting in aggressive behaviors and defensive reactions (Mullin \& Hinshaw, 2007).

Additionally, the model confirmed hypothesis 2 and we verified that the direct path between coparental triangulation and conflict and externalizing problems remained significant in the model, corroborating previous studies (Davies, Hentges, et al., 2016; Schoppe-Sullivan et al., 2009). However, notably, these studies also considered mediating variables between coparenting and externalizing problems, such as adaptive family structure.

Low impact between latent variables and high levels of dimensions of difficulty in emotion regulation may indicate other variables develop externalizing problems. It also explains the direct route between coparental triangulation and conflict and externalizing problems. Literature points out that emotional reactivity, brain maturational factors, physiological processes, insecure attachment, temperament, reading and information process deficits, and empathy deficits may cause externalizing problems (Barros \& Silva, 2006; Davies, Martin, Coe, et al., 2016; Gross, 2014; Mullin \& Hinshaw, 2007; Schoppe-Sullivan et al., 2009). Halligan et al. (2013) indicated externalizing behaviors may associate with poor vagal regulation and with difficulties in emotion regulation. These studies results point to a multiplicity of variables involved in developing externalizing behaviors, which may imply lower levels of impact among the latent variables of this study.

Analysis of the negative dimensions of coparenting found high impact for coparental triangulation (father, mother, and family member). Buehler and Welsh (2009) corroborated this result finding associations between coparental triangulation and antisocial behaviors in adolescents. However, the metaanalysis by Teubert and Pinquart (2010), which analyzed coparenting and children adjustment, found that coparental triangulation has traditionally been associated with internalizing problems. From a developmental point of view, age may moderate the impact of coparenting dimensions on healthy offspring development. Thus, considering maturational capacity and the ability to understand processes that occur in the family nucleus, deducibly, the perception and sensitivity to the impact of coparental triangulation increases in adolescence (Davies, Hentges, et al., 2016).

Thus, coparental triangulation is notably important in this model. Father coparental triangulation had the highest impact on coparenting $(\beta=0.74 ; p<0.001)$, together with mother coparental triangulation $(\beta=0.60 ; p<0.001)$. This indicates that in the context of externalizing problems both father and mother are perceived to actively act negatively in the coparental context (Lamela et al., 2010; Marsanić \& Kusmić, 2013). The hypothesis is that the expression of triangulation is more explicit in this family environment, so that speculatively, parents impose on their children the choice to support one parent against the other, as well as they ostensibly place their children at the center of their coparental and marital conflicts.

Severe antisocial behaviors had the lowest impact in externalizing problems $(\beta=0.45 ; p<0.001)$. According to (Halligan et al., 2013; Mullin \& Hinshaw, 2007), difficulties in finding adaptive strategies to regulate emotions may play a minor role in the practice of proactive externalizing behaviors. This dimension involves ingenious and covert behaviors, such as lying and manipulating. Children and adolescents with high levels of antisocial behavior may lack emotion and exhibit propensity for serious conduct problems, as well as a lower level of emotional reactivity, thus explaining its low impact in the model (Mullin \& Hinshaw, 2007).

This study presented some limitations. Firstly, the scope of the study has a cross-sectional approach, so longitudinal studies can confirm the mediation and outcome proposed here. Regarding the mediation hypothesis, not measuring the significance of indirect effects with the bootstrap procedure- used to test mediation relationships between variables - is another study limitation.

Still, notably, authors who study emotion regulation (Mullin \& Hinshaw, 2007) analyze problems related to impulse control, focus of attention and hyperactivity separately from antisocial behaviors and aggressiveness. In this sense, this study is also limited by essentially assessing problems related to aggressive behaviors and non-compliance with expected behavioral patterns, identified with the dimension of aggressive behavior, YSR rule breaking and mild antisocial behavior and severe antisocial behavior from ABS. Further research aimed at assessing characteristics of specific disorders, such as attention deficit and hyperactivity, should focus on variables not focused in this study, such as attention.

Evidence shows the development of externalizing problems has a multifactorial origin, which explains both direct and indirect links between multiple variables. In this context, emotion regulation and difficulties in the exercise of coparenting are processes that influence the expression of these behaviors to a greater or lesser extent. Recognizing the ways in which each of these factors interfere with the formation and maintenance of aggressiveness enables intervention and prevention of healthier ways to deal with adversity, especially with family. In this sense, future treatment and prevention proposals are necessary for families that consider this study variables aiming at coparental relationships with higher levels of support and cooperation and lower levels of conflict and especially triangulation, assuming the consequent reduction of behavioral and social problems and increased welfare in adolescents. 


\section{References}

Aldao, A., Gee, D. G., De Los Reyes, A., \& Seager, I. (2016). Emotion regulation as a transdiagnostic factor in the development of internalizing and externalizing psychopathology: Current and future directions. Development and Psychopathology, 28(4, Pt. 1), 927-946. doi: $10.1017 /$ S0954579416000638

Achenbach, T. M., \& Rescorla, L. A. (2001). Manual for the ASEBA school-age forms \& profiles: An integrated system of multi-informant assessment. Burlington, VT: ASEBA.

Achenbach, T. M., Ivanova, M. Y., Rescorla, L. A., Turner, L. V., \& Althoff, R. R. (2016). Internalizing/externalizing problems: Review and recommendations for clinical and research applications. Journal of the American Academy of Child \& Adolescent Psychiatry, 55(8), 647-656. doi:10.1016/j.jaac.2016.05.012

Barros, P., \& Silva, F. B. N. (2006). Origem e manutenção do comportamento agressivo na infância e adolescência [Origin and maintenance of aggressive behavior in childhood and adolescence]. Revista Brasileira de Terapias Cognitivas, 2(1), 55-66. Retrieved from http://pepsic.bvsalud.org/scielo.php? script $=$ sci arttext\&pid=S1808-56872006000100006

Byrne, B. M. (2010). Structural equation modeling with AMOS: Basic concepts, applications, and programming (2nd ed.). New York, NY: Routledge.

Bordin, I. A. Rocha, M. M., Paula, C. S., Teixeira, M. C. T. V, Achenbach, T. M., Rescorla, L. a, \& Silvares, E. F. M. (2013). Child Behavior Checklist (CBCL), Youth SelfReport (YSR) and Teacher's Report Form (TRF): an overview of the development of the original and Brazilian versions. Cadernos de Saúde Pública, 29(1), 13-28. https://doi.org/10.1590/S0102-311X2013000500004

Buehler, C., \& Welsh, D. P. (2009). A process model of adolescents' triangulation into parents' marital conflict: The role of emotional reactivity. Journal of Family Psychology, 23(2), 167-180. doi:10.1037/a0014976

Coutinho, J., Ribeiro, E., Ferreirinha, R., \& Dias, P. (2010). Versão portuguesa da escala de dificuldades de regulação emocional e sua relação com sintomas psicopatológicos [The Portuguese version of the difficulties in emotion regulation scale and its relationship with psychopathological symptoms]. Revista de Psiquiatria Clínica, 37(4), 145-151. doi:10.1590/ S0101-60832010000400001

Davies, P. T., Hentges, R. F., Coe, J. L., Martin, M. J., SturgeApple, M. L., \& Cummings, E. M. (2016). The multiple faces of interparental conflict: Implications for cascades of children's insecurity and externalizing problems. Journal of Abnormal Psychology, 125(5), 664-678. doi:10.1037/abn0000170
Davies, P. T., \& Martin, M. J. (2013). The reformulation of emotional security theory: The role of children's social defense in developmental psychopathology. Development and Psychopathology, 25(4, Pt. 2), 14351454. doi:10.1017/S0954579413000709

Davies, P. T., Martin, M. J., Coe, J. L., \& Cummings, E. M. (2016). Transactional cascades of destructive interparental conflict, children's emotional insecurity, and psychological problems across childhood and adolescence. Development and Psychopathology, 28(3), 653-671. doi:10.1017/S0954579416000237

Davies, P. T., Martin, M. J., Sturge-Apple, M. L., Ripple, M. T., \& Cicchetti, D. (2016). The distinctive sequelae of children's coping with interparental conflict: Testing the reformulated emotional security theory. Developmental Psychology, 52(10), 1646-1665. doi:10.1037/dev0000170

Eisenberg, N., Cumberland, A., Spinrad, T. L., Fabes, R. A., Shepard, S. A., Reiser, M.,... Guthrie, I. K. (2001). The relations of regulation and emotionality to children's externalizing and internalizing problem behavior. Child Development, 72(4), 1112-1134. doi:10.1111/1467-8624.00337

Goulart, V. R., Wagner, A., Barbosa, P. V., \& Mosmann, C. P. (2015). Repercussões do conflito conjugal para o ajustamento de crianças e adolescentes: Um estudo teórico. [Effects of marital conflict for children's adjustament: A theoretical study]. Interação em Psicologia, 19(1), 147-159. doi:10.5380/psi.v19i1.35713

Grangeiro, A. S. M. (2014). Escala de comportamento antissociais: Construção e evidências de validade [Scale of antisocial behaviors: Construction and evidence of validity] (Master thesis). Retrieved from http://www.repositorio.ufc.br/handle/riufc/7744

Gratz, K. L., \& Roemer, L. (2004). Multidimensional assessment of emotion regulation and dysregulation: Development, factor structure, and initial validation of the difficulties in emotion regulation scale. Journal of PsychopathologyandBehavioralAssessment, 26(1),41-54. doi:10.1023/B:JOBA.0000007455.08539.94

Gross, J. J. (2014). Handbook of emotion regulation (2nd ed.). New York, NY: Guildford.

Hair, J. F., Jr., Black, W. C., Babin, B. J., Anderson, R. E., \& Tatham, R. L. (2009). Análise multivariada de dados [Multivariate data analysis] (A. S. Sant'Anna, Trad., 6th ed.). Porto Alegre, RS: Bookman.

Halligan, S. L., Cooper, P. J., Fearon, P., Wheeler, S. L., Crosby, M., \& Murray, L. (2013). The longitudinal development of emotion regulation capacities in children at risk for externalizing disorders. Development and Psychopathology, 25(2), 391-406. doi:10.1017/ S0954579412001137 
Lamela, D., Nunes-Costa, R., \& Figueiredo, B. (2010). Modelos teóricos das relações coparentais: Revisão crítica [Theoretical models of coparenting relations: Critical review]. Psicologia em Estudo, 15(1), 205-216. doi:10.1590/S1413-73722010000100022

Margolin, G., Gordis, E. B., \& John, R. S. (2001). Coparenting: A link between marital conflict and parenting in two-parent families. Journal of Family Psychology, 15(1), 3-21. doi:10.1037//0893-3200.15.1.310.1037/0893-3200.15.1.3

Marsanić, V. B., \& Kusmić, E. (2013). Coparenting within the family system: Review of literature. Collegium Antropologicum, 37(4), 1379-1383.

Mosmann, C., Costa, C. B., Silva, A. G. B., \& Luz, S. K. (2018). Children with clinical psychological symptoms: The discriminant role of conjugality, coparenting and parenting. Trends in Psychology, 26(1), 429-442. doi:10.9788/tp2018.1-17pt

Mosmann, C. P., Costa, C. B., Einsfeld, P., Silva, A. G. M., \& Koch, C. (2017). Conjugalidade, parentalidade e coparentalidade: Associações com sintomas externalizantes e internalizantes em crianças e adolescentes [Marital relations, parenting, and coparenting: Associations with externalizing and internalizing symptoms in children and adolescentes]. Estudos de Psicologia (Campinas), 34(4), 487-498. doi:10.1590/1982-02752017000400005

Mullin, B. C., \& Hinshaw, S. P. (2007). Emotion regulation and externalizing disorders in children and adolescents. In J. J. Gross (Ed.), Handbook of emotion regulation (pp. 523-541). New York, NY: Guilford.

Riediger, M., \& Klipker, K. (2014). Emotion regulation in adolescence. In J. J. Gross (Ed.), Handbook of emotion regulation (2nd ed., pp. 187-202). New York, NY: Guilford.

Riina, E. M., \& McHale, S. M. (2014). Bidirectional influences between dimensions of coparenting and adolescent adjustment. Journal of Youth and Adolescence, 43(2), 257-269. doi:10.1007/s10964-013-9940-6

Schoppe-Sullivan, S. J., Weldon, A. H., Cook, J. C., Davis, E. F., \& Buckley, C. K. (2009). Coparenting behavior moderates longitudinal relations between effortful control and preschool children's externalizing behavior. Journal of Child Psychology and Psychiatry, 50(6), 698-706. doi:10.1111/j.1469-7610.2008.02009.x

Teubert, D., \& Pinquart, M. (2010). The association between coparenting and child adjustment: A meta-analysis. Parenting: Science and Practice, 10(4), 286-307. doi:10.1080/15295192.2010.492040

Teubert, D., \& Pinquart, M. (2011). The Coparenting Inventory for Parents and Adolescents (CI-PA): Reliability and validity. European Journal of Psychological Assessment, 27(3), 206-215. doi:10.1027/1015-5759/a000068
Thompson, R. A. (2014). Socialization of emotion and emotion regulation in the family. In J. J. Gross (Ed.), Handbook of emotion regulation (2nd ed., pp. 173-186). New York, NY: Guilford.

Veloso, M., Gouveia, J. P., \& Dinis, A. (2011). Estudos de validação com a versão portuguesa da Escala de Dificuldades na Regulação Emocional (EDRE) [Validity studies with the Portuguese version of Difficulties in Emotion Regulation Scale (EDRE)]. Psychologica, (54), 87-100. Retrieved from http://impactum-journals.uc.pt/ index.php/psychologica/article/view/1102

Mariana Rodrigues Machado is a Professor in Faculdade de Psicologia of the Faculdade Especializada na Área da Saúde do Rio Grande do Sul-FASURGS, Passo Fundo-RS, Brazil.

Clarisse Pereira Mosmann is a Professor in the Programa de Pós Graduação em Psicologia of the Universidade do Vale do Rio dos Sinos, São Leopoldo-RS, Brazil.

\section{Authors' Contribution:}

All authors made substantial contributions to the conception and design of this study, to data analysis and interpretation, and to the manuscript revision and approval of the final version. All the authors assume public responsibility for the manuscript content.

Received: June 10, 2017

1st Revision: Oct. 29, 2017

2nd Revision: Mar. 16, 2018

3rd Revision: Apr. 21, 2018

Approved: May 4, 2018

How to cite this article:

Machado, M. R., \& Mosmann, C. P. (2020). Coparental conflict and triangulation, emotion regulation, and externalizing problems in adolescents: Direct and indirect relationships. Paidéia (Ribeirão Preto), 30, e3004. doi:http://dx.doi.org/10.1590/1982-4327e3004 